\title{
Method Validation of Esomeprazole Analysis in Human Plasma using High Performance Liquid Chromatography-Photodiode Array
}

Yahdiana Harahap, Ahmad Erik Baskara, Harmita

Faculty of Pharmacy, University of Indonesia, UI Depok Campus, Depok, 16424, INDONESIA.

\begin{abstract}
Objective: This research aimed to develop sensitive, simple, and selective methods for determination of esomeprazole in human plasma using lansoprazole as internal standard by high performance liquid chromatography. Method: The analytical separation was performed on C-18 column (Waters, Sunfire ${ }^{\mathrm{TM}} 5 \mu \mathrm{m} ; 250 \times 4.6 \mathrm{~mm}$ ), column temperature $40^{\circ} \mathrm{C}$. The mobile phase used acetonitrile - phosphate buffer $\mathrm{pH} 7.6$ (40: 60\% v/v) with a flow rate of $1.00 \mathrm{~mL} / \mathrm{min}$; and photodiode array detector at a wavelength of $300 \mathrm{~nm}$. Esomeprazole and lansoprazole were extracted by liquid-liquid extraction using dichloromethane. Results: The method had a chromatographic run time of $10 \mathrm{~min}$ and linear calibration curve over the range of 5.0-450 ng/mL with a correlation coefficient (r) of 0.999 or better. The sensitivity, specificity, linearity, precision and accuracy, recovery
\end{abstract}

and stability were validated for esomeprazole in human plasma. Conclusion: The results of validation fulfilled the acceptance criteria of validation method based on EMEA Bioanalytical Guideline 2011.

Key words: Esomeprazole, HPLC, Optimization, Validation, Plasma.

Correspondence :

Yahdiana Harahap

Faculty of Pharmacy, University of Indonesia,

UI Depok Campus, Depok, 16424, INDONESIA.

Phone no: +6221-78849001-003

Email:yahdiana03@yahoo.com

DOI: 10.5530/jyp.2017.1s.7

\section{INTRODUCTION}

GERD (Gastroesophageal Reflux Disease) refers to symptoms that resulted from repeated abnormal reflux of the stomach contents into the esophagus, especially after having some meal. Only few patients seek medical treatment because patients usually suffer from mild symptoms and could be relieved after self-treatment using antacids. Therefore, only severe cases followed with endoscopy disturbance and other complications that seek medical treatment. The prevalence of GERD appears highest in Western countries, such as the United Kingdom and United States which estimated $20 \%$ of the total populations suffer from GERD symptoms. This condition is not well-known in Asia and the prevalence range was estimated $2 \%$ to $6 \%$. However, the consequences of eating habit and modern lifestyle nowadays are a tendency to have an increased GERD sufferer in Asia. ${ }^{1}$

Esomeprazole is the S-isomer of omeprazole which works by inhibiting the proton pump or so-called proton pump inhibitor (PPI). ${ }^{1,2}$ In adult patients, esomeprazole is indicated for the treatment and to maintain GERD recovery symptoms and erosive esophagitis as alternative treatment besides NSAID for gastric ulcer and can be combined with antibiotic to treat Helicobacter pylori infection and duodenum ulcer diseases. The proton pump inhibitor drug act in an irreversible bind and inhibit proton pump in the parietal cell. ${ }^{3}$

However, esomeprazole is very sensitive to acidity, heat, humidity, oxidation, thus the stability tends to be reduced during long-term storage. ${ }^{3}$ Therefore, a stability testing should be conducted. The stability testing was conducted in some methods, including the short-term stability, long-term stability, until freeze and thaw stability tests.

In the developed method before using HPLC and metronidazole as the internal standard, the LLOQ value was $50.57 \mathrm{ng} / \mathrm{mL},{ }^{5}$ while the LLOQ value should be $22.5 \mathrm{ng} / \mathrm{mL}$. This condition was related with the esomeprazole Cmax value because the LLOQ value was $1 / 20$ of the esomeprazole Cmax value which was $450 \mathrm{ng} / \mathrm{mL}$. Thus a validated analytical method development is needed to provide a better LLOQ and can be used for pharmacokinetic studies.

\section{MATERIALS AND METHODS}

\section{Chemical and Reagents}

Esomeprazole (EQEsteve), Lansoprazole (SigmaAldrich), Acetonitrile Pro HPLC (Merck), Methanol Pro HPLC (Merck), Sodium dihydrogen phosphate (Merck), Disodium hydrogen phosphate (Merck), Aquabidest (Ikapharmindo), Dichloromethane (Merck), human plasma (Indonesian Red Cross).

\section{Instruments}

High Performance Liquid Chromatography equipped with pumps, autosampler, column C-18 (Waters, Sunfire ${ }^{\mathrm{TM}} 5 \mu \mathrm{m} ; 250$ x $4.6 \mathrm{~mm}$ ), photodiode array detector (Waters 2996), and data processor; $\mathrm{pH}$ meter (Eutech pH 510); Whatman Filter; Degasser; Centrifuge (Digisystem DSC-300SD); Freezer (Biomedical Labtech Deep Freezer); Evaporator (TurboVap LV).

\section{Chromatography System}

This study was implemented using C- 18 column, $5 \mu \mathrm{m}, 250 \times 4.6 \mathrm{~mm}$ in HPLC method. Injection volume was $20 \mu \mathrm{L}$ and was detected at $300 \mathrm{~nm}$ with the flow rate of $1 \mathrm{~mL} / \mathrm{min}$. 


\section{Preparation of Standard Solution}

$10.0 \mathrm{mg}$ esomeprazole was weighed then dissolved in the mobile phase (40 mM sodium dihydrogen phospate buffer, $\mathrm{pH}$ 7.6-acetonitrile) in 10 $\mathrm{mL}$ volumetric flask to obtain $1.0 \mathrm{mg} / \mathrm{mL}(1000 \mathrm{ppm})$ concentration. Lansoprazole standard was weighed for $10.0 \mathrm{mg}$ and was dissolved with the mobile phase in $10.0 \mathrm{~mL}$ volumetric flask to obtain $1.0 \mathrm{mg} / \mathrm{mL}$ (1000 $\mathrm{ppm}$ ). The dilution was conducted to obtain solutions in certain concentrations.

\section{Preparation of Mobile Phase}

Disodium hydrogen phosphate was weighed for 1.118 gram and sodium dihydrogen phosphate for 0.181 gram then dissolved in $250 \mathrm{~mL}$ water. The acidity value of the solution was checked then phosphoric acid was added so that the $\mathrm{pH}$ value would be 7.6. Then $240 \mathrm{~mL}$ was taken from the phosphate buffer solution, and mixed with $160 \mathrm{~mL}$ acetonitrile to obtain acetonitrile-phosphate buffer mixtures in 40:60 ratio.

\section{Plasma Sample Preparations}

The liquid-liquid extraction method was conducted by adding $25 \mu \mathrm{L}$ lansoprazole $50 \mu \mathrm{g} / \mathrm{mL}$ in $500 \mu \mathrm{L}$ plasma which contained esomeprazole in $50 \mu \mathrm{g} / \mathrm{mL}$ concentrations, and vortexed for 10 seconds. Next, $5 \mathrm{~mL}$ dichloromethane was added, and the mixtures were vortexed for $3 \mathrm{mins}$ then centrifuged at 3,000 rpm for 15 mins. The $4 \mathrm{~mL}$ organic phase was transferred to another tube and evaporated, then the residue was reconstituted in $100 \mu \mathrm{L}$ mobile phase in the vial then was sonicated and vortexed for 2 mins. Afterward $20.0 \mu \mathrm{L}$ aliquot was injected into HPLC system.

\section{Optimization of Esomeprazole Analytical Condition Using High-Performance Liquid Chromatography}

The $20 \mu \mathrm{L}$ mixture of $50.0 \mu \mathrm{g} / \mathrm{mL}$ esomeprazole and $50.0 \mu \mathrm{g} / \mathrm{mL}$ lansoprazole were injected into the HPLC device and the chromatography response was observed. The optimization was started by choosing the wavelength for the analysis. Esomeprazole analysis was conducted in the maximum wavelength which was obtained using PDA detector at 300 $\mathrm{nm}$. The optimized mobile phase was conducted using the mixtures of methanol-phosphate buffer, acetonitrile-phosphate buffer, and acetonitrile-methanol-phosphate buffer. Then optimizing the mobile phase composition and the $\mathrm{pH}$ of the mobile phase, flow rate, and the column temperature. The mobile phase composition was optimized in the ratios of $45: 55,40: 60$, and 35:65 followed by the $\mathrm{pH}$ of the mobile phase in 7 , 7.5 , and 8 . The flow rate of the mobile phase was optimized in $0.8,1.0$, and $1.2 \mathrm{~mL} / \mathrm{min}$. The column temperature was optimized in $30^{\circ} \mathrm{C}, 35^{\circ} \mathrm{C}$, $40^{\circ} \mathrm{C}$, and $45^{\circ} \mathrm{C}$.

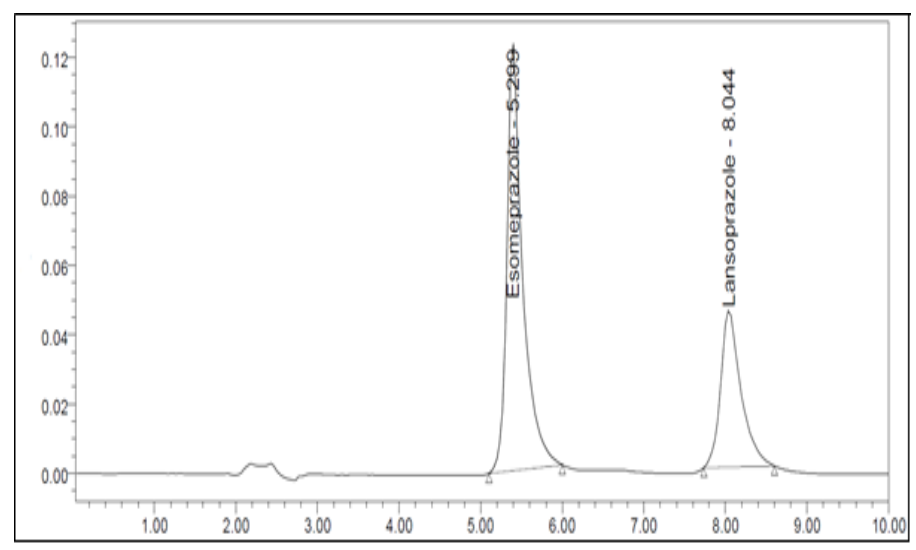

Figure 1: Chromatogram System Suitability Test Result of Esomeprazole and Lanzoprazole.

\section{System Suitability Test}

After obtaining the optimum conditions for esomeprazole analysis esomeprazole solutions was injected along with internal standard with six times repetition. The coefficient variation $(\mathrm{CV})$ requirements or the repetitive time retention and the area of each compound that would be measured as PAR should be $<2.0 \%$.

\section{Method Validation of Esomeprazole Analysis in Plasma}

In this study referring to EMEA Guideline for Bioanalytical Method Validation 2011, ${ }^{6}$ full validation of esomeprazole analytical method in plasma was conducted with selectivity, carry over, LLOQ, linear calibration curve, accuracy, precision, and recovery, dilution integrity, and stability parameters.

\section{RESULTS AND DISCUSSION}

\section{Optimization of Esomeprazole Analysis using High- Performance Liquid Chromatography}

Optimization condition of esomeprazole analysis was started from optimizing the wavelength, then optimizing the mobile phase type. The mobile phase type should be chosen to obtain the perfect chromatogram. (Figure 1-5). From three combinations of the mobile phase, the combination that provides the highest peak respond was the acetonitrile phosphate buffer (40:60) combinations in the $\mathrm{pH}$ value of 7.6. Then the flow rate was optimized. In the $1.20 \mathrm{~mL} / \mathrm{min}$, the flow rate retention was too fast, therefore, it was worried that during the analysis the esomeprazole plasma peak would be merged with the interference. While in the $0.8 \mathrm{~mL} / \mathrm{min}$, the flow rate was too slow and the resolution was quite high so that it needed longer analysis time. Moreover the flow rate affected the column pressure, in which higher flow rate increases the column pressure. Therefore, this study chose the $1.0 \mathrm{~mL} / \mathrm{min}$ flow rate. Next, the column temperature was optimized. The obtained results showed that higher column temperature could increase the retention time and reduce the resolution. The highest area was found in $35^{\circ} \mathrm{C}$, but there was a high tailing factor. Thus, the used column temperature was $40^{\circ} \mathrm{C}$ because of the high area value and the lowest tailing factor.

Esomeprazole analysis which was detected using photodiode array detector at $300 \mathrm{~nm}$ wavelength was found in the optimum condition using $\mathrm{C}_{18}$ column (Waters, Sunfire ${ }^{\mathrm{TM}} 5 \mu \mathrm{m}, 250 \times 4.6 \mathrm{~mm}$ ), acetonitrile - phosphate buffer (40:60) mobile phase in $\mathrm{pH} 7.6$, flow rate of $1.0 \mathrm{~mL} / \mathrm{min}$, column temperature of $40^{\circ} \mathrm{C}$, using lansoprazole as the internal standard. The analytical condition was chosen because it provides the highest separation parameter, including the highest area, the fastest relative

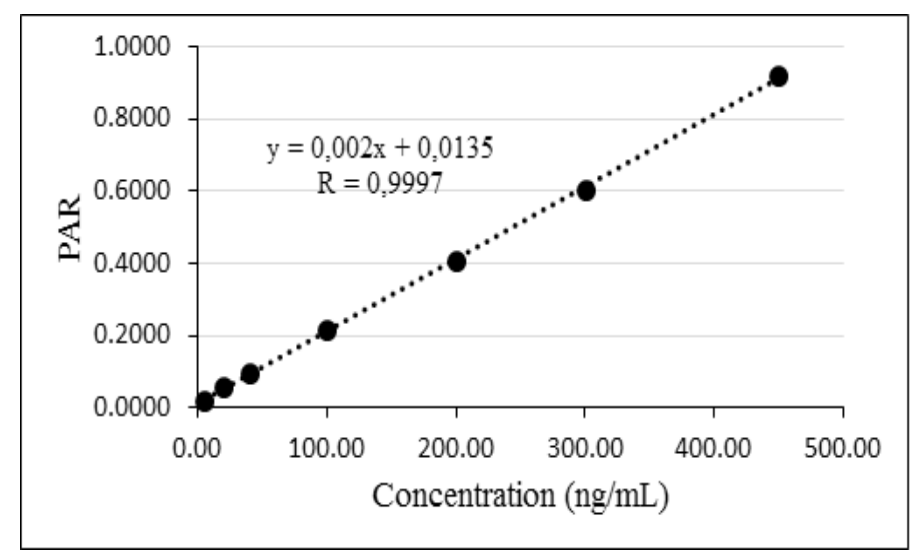

Figure 2: A representative calibration curve of Esomeprazole. 


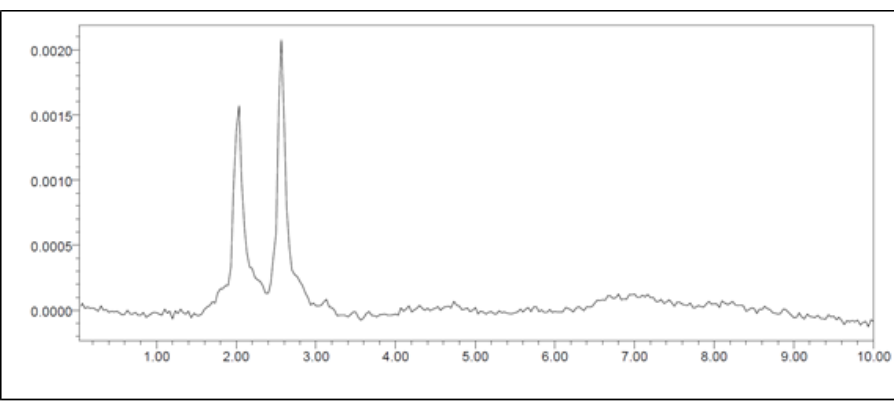

Figure 3: A representative chromatogram of blank plasma.

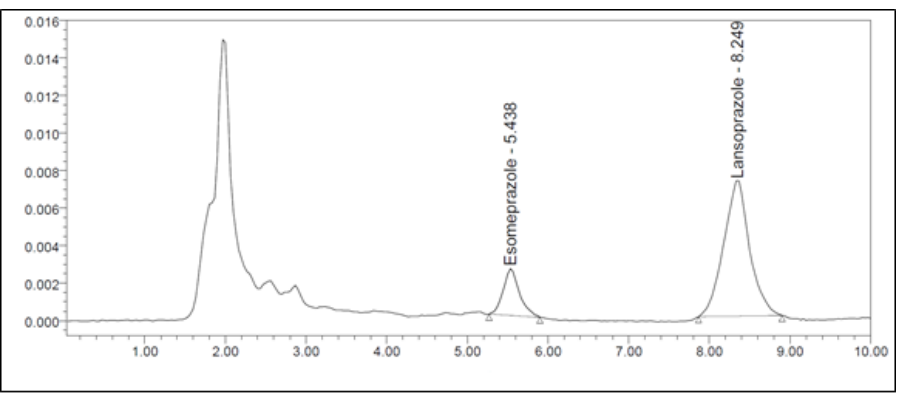

Figure 5: A representative chromatogram of ULOQ.

retention time, tailing factor $\left(T_{f}\right)$ that was almost 1 , resolution $(R)>2$, the highest theoretical plate $(\mathrm{N})$, and HETP close to 0.

\section{System Suitability Test}

After obtaining the optimum analytical condition, the system suitability test was conducted with six times injection. The obtained results were expressed in retention time, area, and PAR with $\mathrm{CV}$ value $<2.0 \%$.

\section{Validation Method of Esomeprazole Analysis in the Plasma}

\section{Selectivity}

Selectivity test was conducted in the blank plasma and LLOQ concentrations by using plasma from six different sources. The study results showed no interferences in the retention time of the analyte and the internal standard.

\section{Carry Over}

The study showed no carry over effect in the blank plasma after injecting the highest concentration (ULOQ) of esomeprazole. The carry over percentage still meets the requirements for analyte $<20 \%$. The results of carry over test are shown in Table 1.

\section{Calibration Curve and LLOQ}

Calibration curve was linear with the correlation coefficient $(r>0.9997)$ in concentration range from 5.0 to $450.0 \mathrm{ng} / \mathrm{mL}$. LLOQ concentration of esomeprazole was $5.0 \mathrm{ng} / \mathrm{mL}$ with the $\mathrm{CV}$ value of $5.89 \%$ and $\%$ diff between -7.69 to $7.32 \%$.

\section{Accuracy, Precision, and Recovery}

Accuracy and precision test were conducted in within run and between run on 4 different concentrations, such as LLOQ, QCL, QCM, and QCH. The accuracy and precision results of the within run and between run are showed in Table 2. The absolute recovery test was conducted to compare the analyte peak respond in the plasma with the standard in the solution.

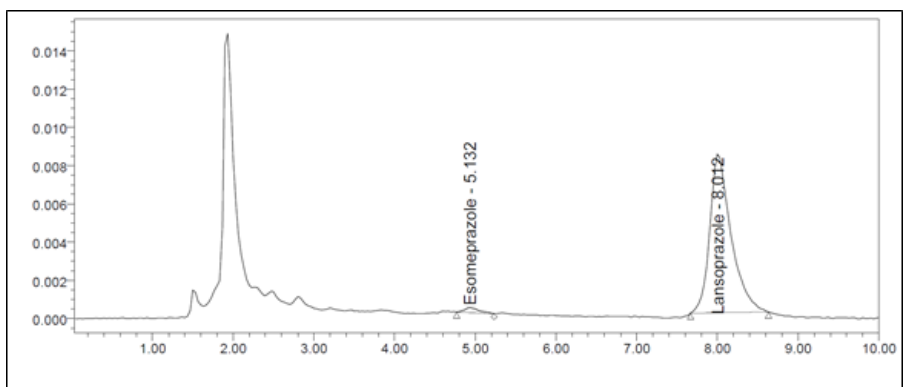

Figure 4: A representative chromatogram of LLOQ.

Table 1: Carry over measurement data

\begin{tabular}{ccc}
\hline Blank sample & Carry over esomeprazol (\%) & Carry over IS (\%) \\
\hline Blank-1 & 8.32 & 0.42 \\
Blank-2 & 4.59 & 0.50 \\
Blank-3 & 6.51 & 0.29 \\
Blank-4 & 2.88 & 0.38 \\
Blank-5 & 7.22 & 0.40 \\
Mean & 5.90 & 0.40 \\
\hline
\end{tabular}

\section{Dilution Integrity}

Dilution integrity test was conducted to determine the accuracy, precision, and reliability of the dilution process in bioanalytical process. If the in vivo esomeprazole assay in the biologic matrix obtained more than the highest requirement in $450 \mathrm{ng} / \mathrm{mL}$, then should conduct a dilution process so that the concentration could meet the calibration curve range. Results obtained shown in Table 3.

\section{Stability}

Stability was analyzed using QCL and QCH samples, each with three replications. For the short-term stability, samples were stored in room temperature and the stability was observed in 0,6 , and 24 hours. The obtained results showed that esomeprazole samples were stable to be stored in the room temperature minimum 24 hours (Table 4). For longterm stability, samples were stored in the freezer in $-20^{\circ} \mathrm{C}$ and $-80^{\circ} \mathrm{C}$ for 7 and 14 days. The obtained results showed that esomeprazole samples were stable to be stored in the freezer in $-20^{\circ} \mathrm{C}$ and $-80^{\circ} \mathrm{C}$ minimum 14 days (Table 5 and Table 6 ). Freeze-thaw stability test was also conducted. Esomeprazole in the plasma was found stable after freeze-thaw test in three cycles minimum. Results are shown in Table 7 . The obtained results from the autosampler stability test were shown in Table 8. Those results showed that the prepared omeprazole was stable minimum $24 \mathrm{~h}$ in autosampler.

The short-term stability of standard solutions of esomeprazole and the internal standard were tested in room temperature for $24 \mathrm{~h}$. The long-term stability of the standard solutions were stored in $4^{\circ} \mathrm{C}$ for 7 and 14 days. The obtained results showed \%diff for the short-term stability of esomeprazole was from $-1.95 \%$ to $1.99 \%$ and \%diff for lansoprazole short-term stability was from -1.85 to $-1.64 \%$. This showed that the esomeprazole solutions and lansoprazole solutions were stable when stored in room temperature for minimum $24 \mathrm{~h}$. For long-term stability, the obtained results of \%diff esomeprazole were between $-2.06 \%$ to $-1.96 \%$ and \%diff for lansoprazole solutions were between $-1.81 \%$ to $-1.57 \%$ for 14 days in $4^{\circ} \mathrm{C}$. Therefore, esomeprazole and lansoprazole stock solutions could be used for 14 days. 
Table 2: Within run and between run accuracy and precision

\begin{tabular}{ccccccc}
\hline \multirow{2}{*}{$\begin{array}{c}\text { Actual Const. } \\
(\mathrm{ng} / \mathrm{mL})\end{array}$} & \multicolumn{2}{c}{ Within Run } & \multicolumn{4}{c}{ Between Run } \\
\cline { 2 - 8 } & $\begin{array}{c}\text { Measurable Const. } \\
\text { (Mean } \pm \text { SD; } \mathbf{n g} / \mathrm{mL})\end{array}$ & CV (\%) & Bias (\%) & $\begin{array}{c}\text { Measurable Const. } \\
\text { (Mean } \pm \text { SD; } \mathbf{n g} / \mathbf{m L})\end{array}$ & CV (\%) & Bias (\%) \\
\hline 5.0 & $5.29 \pm 0.57$ & 10.80 & 5.86 & $5.12 \pm 0.52$ & 10.22 & 2.41 \\
15.0 & $15.63 \pm 1.49$ & 9.51 & 4.21 & $14.84 \pm 1.19$ & 8.03 & -1.1 \\
\hline 222.5 & $243.68 \pm 1.81$ & 0.74 & 9.52 & $227.94 \pm 15.47$ & 6.79 & 2.45 \\
\hline 337.5 & $342.14 \pm 16.86$ & 4.93 & 1.37 & $338.02 \pm 23.22$ & 6.87 & 0.16 \\
\hline
\end{tabular}

Table 3: Within run and between run dilution integrity test data

\begin{tabular}{|c|c|c|c|c|c|c|c|}
\hline $\begin{array}{l}\text { Actual } \\
\text { Const. } \\
\text { (ng/mL) }\end{array}$ & Dilution Factor & \multicolumn{3}{|c|}{ Within Run } & \multicolumn{3}{|c|}{ Between Run } \\
\hline 168.8 & $1 / 4$ & $166.90 \pm 3.56$ & 2.13 & -1.10 & $166.53 \pm 4.90$ & 2.94 & -1.31 \\
\hline
\end{tabular}

Table 4: Esomeprazole short-term stability in the plasma in room temperature

\begin{tabular}{ccccccc}
\hline \multirow{2}{*}{ Time } & \multicolumn{2}{c}{ QCL 15.0 $\mathrm{ng} / \mathrm{mL}$} & \multicolumn{2}{c}{ QCH 337.5 $\mathrm{ng} / \mathrm{mL}$} \\
\cline { 2 - 8 } & $\begin{array}{c}\text { Measurable Const. } \\
\text { (Mean } \pm \text { SD; } \mathbf{n g} / \mathrm{mL} \text { ) }\end{array}$ & CV (\%) & Bias (\%) & $\begin{array}{c}\text { Measurable Const. } \\
\text { (Mean } \pm \text { SD; } \mathbf{n g} / \mathrm{mL})\end{array}$ & CV (\%) & Bias (\%) \\
\hline 0 hour & $15.35 \pm 0.30$ & 1.96 & 2.34 & $338.47 \pm 2.93$ & 0.87 & 0.29 \\
6 hours & $14.52 \pm 0.46$ & 3.15 & -3.21 & $331.43 \pm 4.17$ & 1.26 & -1.80 \\
24 hours & $13.85 \pm 0.46$ & 3.33 & -7.69 & $316.49 \pm 6.47$ & 2.05 & -6.22 \\
\hline
\end{tabular}

Table 5: Esomeprazole long-term stability in the plasma in $-20^{\circ} \mathrm{C}$

\begin{tabular}{cccccccc}
\hline & \multicolumn{2}{c}{ QCL 15.0 $\mathrm{ng} / \mathrm{mL}$} & \multicolumn{3}{c}{ QCH 337.5 $\mathrm{ng} / \mathrm{mL}$} \\
\cline { 2 - 8 } Day & $\begin{array}{c}\text { Measurable Const. } \\
\text { (Mean } \pm \text { SD; } \mathbf{n g} / \mathrm{mL})\end{array}$ & CV (\%) & Bias (\%) & $\begin{array}{c}\text { Measurable Const. } \\
\text { (Mean } \pm \text { SD; } \mathbf{n g} / \mathrm{mL})\end{array}$ & CV (\%) & Bias (\%) \\
\hline 0 & $15.32 \pm 0.39$ & 2.56 & 2.13 & $337.67 \pm 2.08$ & 0.62 & 0.05 \\
7 & $14.81 \pm 0.28$ & 1.92 & -1.29 & $328.86 \pm 6.70$ & 2.04 & -2.56 \\
14 & $14.29 \pm 0.28$ & 1.94 & -4.71 & $316.95 \pm 6.87$ & 2.17 & -6.09 \\
\hline
\end{tabular}

\section{Table 6: Esomeprazole long-term stability in the plasma in $-80^{\circ} \mathrm{C}$}

\begin{tabular}{|c|c|c|c|c|c|c|}
\hline \multirow{3}{*}{ Day } & \multicolumn{3}{|c|}{$\mathrm{QCL} 15.0 \mathrm{ng} / \mathrm{mL}$} & \multicolumn{3}{|c|}{ QCH $337.5 \mathrm{ng} / \mathrm{mL}$} \\
\hline & Measurable Const. & \multirow{2}{*}{ CV (\%) } & \multirow{2}{*}{ Bias (\%) } & Measurable Const. & \multirow{2}{*}{ CV (\%) } & \multirow{2}{*}{ Bias (\%) } \\
\hline & (Mean \pm SD; $n g / m L)$ & & & (Mean $\pm \mathrm{SD} ; \mathrm{ng} / \mathrm{mL}$ ) & & \\
\hline 0 & $15.63 \pm 0.33$ & 2.13 & 4.21 & $342.84 \pm 4.15$ & 1.21 & 1.58 \\
\hline 7 & $15.08 \pm 0.42$ & 2.81 & 0.52 & $332.45 \pm 3.40$ & 1.02 & -1.50 \\
\hline 14 & $14.70 \pm 0.11$ & 0.77 & -2.03 & $324.79 \pm 1.28$ & 0.39 & -3.77 \\
\hline
\end{tabular}

Table 7: Esomeprazole freeze-thaw stability in the plasma

\begin{tabular}{ccccccc} 
& \multicolumn{2}{c}{ QCL $15.0 \mathrm{ng} / \mathrm{mL}$} & \multicolumn{3}{c}{ QCH 337.5 $\mathrm{ng} / \mathrm{mL}$} \\
\cline { 2 - 8 } Cycle & $\begin{array}{c}\text { Measurable Const. } \\
\text { (Mean } \pm \text { SD; } \mathbf{n g} / \mathrm{mL})\end{array}$ & $\begin{array}{c}\text { CV } \\
(\%)\end{array}$ & Bias (\%) & $\begin{array}{c}\text { Measurable Const. } \\
\text { (Mean } \pm \text { SD; } \mathbf{n g} / \mathrm{mL})\end{array}$ & $\begin{array}{c}\text { CV } \\
(\%)\end{array}$ & Bias (\%) \\
\hline 0 & $15.59 \pm 0.38$ & 2.44 & 3.93 & $343.18 \pm 7.11$ & 2.07 & 1.68 \\
3 & $14.17 \pm 0.12$ & 0.87 & -5.52 & $326.09 \pm 6.10$ & 1.87 & -3.38 \\
\hline
\end{tabular}


Table 8: Esomeprazole after preparation (autosampler) stability in human plasma

\begin{tabular}{ccccccc}
\hline & \multicolumn{2}{c}{ QCL 15.0 ng/mL } & \multicolumn{3}{c}{ QCH 337.5 ng/mL } \\
\cline { 2 - 8 } Hour & $\begin{array}{c}\text { Measurable Const. } \\
\text { (Mean } \pm \text { SD; } \mathbf{n g} / \mathrm{mL})\end{array}$ & CV (\%) & Bias (\%) & $\begin{array}{c}\text { Measurable Const. } \\
\text { (Mean } \pm \text { SD; } \mathrm{ng} / \mathrm{mL})\end{array}$ & $\begin{array}{c}\text { CV } \\
(\%)\end{array}$ & Bias (\%) \\
\hline 0 & $15.54 \pm 0.22$ & 1.42 & 3.58 & $351.52 \pm 6.67$ & 1.90 & 4.15 \\
24 & $14.49 \pm 0.29$ & 2.00 & -3.43 & $326.52 \pm 1.64$ & 0.50 & -3.25 \\
\hline
\end{tabular}

\section{CONCLUSION}

The method was sensitive, selective, and has simple sample preparation. It also fulfilled the EMEA Bioanalytical Guideline 2011 requirements for validations with concentration range of $5.0-450.0 \mathrm{ng} / \mathrm{mL}$.

\section{CONFLICT OF INTEREST}

No conflict of interest are declared.

\section{REFERENCES}

1. DiPiro JT, Talbert RL, Yee G, Matzke G, Wells B, Posey LM. Pharmacotherapy $7^{\text {th }}$ ed. A Pathophysiologic Approach. United States of America: McGraw-Hill; 2008
2. Sweetman, S. C. (2009). Martindale 36th Edition: The Complete Drug Reference. London: Pharmaceutical Press.

3. Zhao J, Jianguo L, Jennifer E, Anderson T, Fulmer T, Illueca M, et al. Pharmacokinetics Properties of Esomeprazole in Children Aged 1 to 11 Years with Symptoms of Gastroesophageal Reflux Disease: A Randomized, Open-Label Study. Clinical Therapeutics. 2006;28(11):1868-76.

4. Reddy PS, Sait S, Vasudevmurthy G, Vishwanath B, Prasad V Reddy, SJ Stability indicating simultaneous estimation of assay method for naproxen and esomeprazol in pharmaceutical formulations by RP-HPLC. 2011;3(6);553-64.

5. Satyadev TNVSS, Sudhir KVR, Tata SB, Sundar S. Development and Validation of High Performance Liquid Chromatographic Method for the Determination of Esomeprazol in Human Plasma. International Journal of Research in Pharmacy and Chemistry. 2013;552-9.

6. European Medicines Agency. Guideline on Bioanalytical Method Validation (Vol. 44). London: An agency of the European Union. 2011

Article History: Submission Date:21-12-16; Revision Date: 07-01-17; Accepted Date:13-01-17.

Cite this article: Harahap Y, Baskara AE, Harmita. Method Validation of Esomeprazole Analysis in Human Plasma using High Performance Liquid Chromatography-Photodiode Array. J Young Pharm. 2017;9(1)Suppl:s24-s8. 